\title{
Morphological characterization of sweet and sour cherry cultivars in a germplasm bank at Portugal
}

\author{
Luciano Cordeiro Rodrigues • María Remedios Morales • \\ Artur João Bártolo Fernandes · Jesús María Ortiz
}

\begin{abstract}
Nine sweet cherry and eight sour cherry varieties located in a germplasm bank at Fundão, Portugal, were studied from the viewpoint of characterization. Most of them were autochthonous cultivars that have a high risk of extinction since at the present they are markedly minor varieties. Morphological characteristics were evaluated in different organs: crown and trunk of the trees, leaves, flowers and fruits, over a three consecutive years period. Statistical analyses were carried out in order to detect similarities between cultivars as well as the existence of synonymies. Qualitative characteristics of the fruits were scored in order to carry out the multivariate analysis. A dendrogram of the evaluated characters shows the marked differentiation between sour and sweet cherries and suggests the existing synonymies. Conservation of the autochthonous cultivars in the future is highly recommended.
\end{abstract}

L. C. Rodrigues - A. J. B. Fernandes

Centro de Investigação da Montanha (CIMO), Instituto Politécnico de Bragança, Apartado 172, Braganca 5301855 , Portugal

M. R. Morales

Facultad de Ciências Agrárias, Universidad de Salamanca, Salamanca 37007, Spain

J. M. Ortiz ( $\bowtie)$

Escuela Técnica Superior de Ingenieros Agrónomos, Universidad Politécnica de Madrid, Madrid 28040, Spain e-mail: jesusmaria.ortizm@upm.es
Keywords Cherry morphology · Cherry synonymies · Endangered varieties $\cdot$ Prunus avium . Prunus cerasus

\section{Introduction}

Sour cherry (Prunus cerasus L.) and sweet cherry (Prunus avium (L.) L.) belong to the family of Rosaceae, subfamily Prunoideae, to the genus Prunus, subgenus Cerasus (Linnaeus 1753). Ingram (1948) divided the subgenus Cerasus into eight subsections according to the form of calyx, pubescence of style and indentation of the mature leaf. Sweet and sour cherries as well as P. fruticosa Pallas, belong to the subsection Eucerasus. Based on archaeological and fossil evidence, sour and sweet cherries seem to be native to Northwest and Central Europe (Watkins 1995). From remains found in caves, it is thought that the wild cherries formed part of the diet of pre-historic man (Hedrick 1915; Marshall 1954).

Olden and Nybom (1968) crossed P. fruticosa with $P$. avium and the hybrid resulted very similar to $P$. cerasus, proposing that they could be considered the parents of the cultivated sour cherry. This species is considered as an alotetraploid with disomic inheritance (Beaver and Iezzoni 1993). RFLP analysis of DNA chloroplasts from sour cherry suggests the parentage of $P$. fruticosa. Hybrids of $P$. avium and $P$. cerasus are found in many cherry collections (Hillig and Iezzoni 1988). 
Morphological characterization of both species can be carried out in different organs of the plant by using descriptors like the ones recommended by the IBPGR (1985). Autochthonous cultivars are in some cases in a high risk of extinction due to the introduction of foreign varieties, which may have a higher productivity or are better known in foreign markets. The complete characterization as well as the conservation of these somewhat neglected cultivars is considered of great importance in order to avoid the loss of this germplasm.

The present study includes seventeen varieties of sour and sweet cherries. The purpose of the study is to examine the individual varieties as well as identify the existing synonymies among them.

\section{Material and methods}

The plant material was located in a field collection on the north side of the 'Sierra de la Gardunha', in Central-East Portugal, near the town of Fundão. The geology of the zone is based on plutonic rocks, granites and derivatives. The soilsare distric cambisols (Instituto do Ambiente 2003). The climate is humid, mesothermic with a high water deficiency in summer and a high water surplus in winter.

The plantation consisted of trees of the varieties indicated in Table 1, grafted in 1991, previously collected at different locations an included in the collection (T. Ferreira, personal communication). 'Lisboeta', 'Francesa de Alenquer' and 'Morangão' appear to have been originally French varieties, adapted to Portugal. 'Maringa' initially thought to be portuguese, although it could have an Italian origin. 'Saco 1' is a variety from Montalegre, Portugal, while 'Saco 2' is the authentic 'De Saco' from Cova da Beira, Portugal, grown by farmers of the region. The three sour cherries 'Sobral, Martinho and Pedro Miguel' 'D`Óbidos', as well as 'Seixas', had been collected in Alcobaça by technicians from the 'Estaçao Nacional de Fruticultura Vieira Natividade' (ENFVN) (Alcobaça, Portugal). 'Galega', ' Garrafal rosa', ' Garrafal' and 'Garrafal negra' were acquired from a private nursery.

Moreover, three varieties of sweet cherry were included as reference cultivars: early 'Precoce Bernard', midseason 'Burlat' and late 'Tardif de Vignole'. 'Garrafal' was the reference for sour cherries.
Between 5 and 10 trees of each variety were sampled, with the exception of 'Garrafal rosa' where only three trees were available. Random samples consisting of 50 flowers, 50 fruits and 50 leaves were collected each of the three years of study.

Flowers were sampled at full bloom. Diameter of the open flower, length of the petals and pistil, with of the petal and the number of stamens were measured or counted.

Adult leaves were sampled in summer, measuring the leaf blade length and width, length of the petiole, and the basal and apical angles of the blade.

Fruits were sampled at maturity, calculating their weight and volume, the volume of the endocarp, length of the stalk and the acidity and sugar levels of the pulp. The percentage of cracking was evaluated by counting the number of cherries cracked when immersed in water. The volume of the fruit and of the endocarp were calculated using the formula $4 / 3 \pi \mathrm{r}^{3}$, where $r=$ [length of the fruit + width of the fruit $] / 4$. In addition, morphological fruit characteristics were evaluated such as the colour of the skin and pulp, shape of the fruit, external discoloration, firmness of the pulp, and the eating quality.

With respect to the trees, only the vigour, habit and compatibility of scion and stock were evaluated.

The characterisation in different organs was carried out by using the IBPGR cherry descriptor (1985) with modifications. Statistical analysis was carried out for the three year period and multivariate analysis of the results was done with the NTSYS software package (Rohlf 1990) by calculating the standardized matrix and using the UPGMA method with the distance coefficient.

\section{Results}

Flowers

Parameters of the flowers are summarized in Table 1. Diameter ranged from 2.9 to 3.7 in sweet cherries, being 'Precoce Bernard' and 'Burlat' the varieties with larger flowers. Sour cherries had always smaller flowers with diameters from 2.5 to $3.0 \mathrm{~cm}$. The number of stamens varied from 35 to 40 in sweet cherries and from 30 to 37 in sour cherries. The length of the pistil was around $1.3 \mathrm{~cm}$ in sweet cherries and near 1.0 in sour cherries. The petal 
Table 1 Flower parameters in sweet (sw) (Prunus avium) and sour (so) (Prunus cerasus) cherry varieties

\begin{tabular}{|c|c|c|c|c|c|}
\hline Variety (Abbreviation) & $\begin{array}{l}\text { Open flower } \\
\text { diameter }(\mathrm{cm})\end{array}$ & $\begin{array}{l}\text { Number of } \\
\text { stamens }\end{array}$ & $\begin{array}{l}\text { Pistil length } \\
(\mathrm{cm})\end{array}$ & $\begin{array}{l}\text { Petal lenght } \\
(\mathrm{cm})\end{array}$ & $\begin{array}{l}\text { Petal width } \\
(\mathrm{cm})\end{array}$ \\
\hline Precoce Bernard (sw) (PrB) & $3.61(0.22)$ & $35.08(2.30)$ & $1.29(0.06)$ & $1.80(0.07)$ & $1.49(0.07)$ \\
\hline Burlat (sw) (Bur) & $3.74(0.29)$ & $38.34(0.89)$ & $1.31(0.07)$ & $1.85(0.12)$ & $1.43(0.10)$ \\
\hline Francesa de Alenquer (sw) (FrA) & $2.88(0.15)$ & $38.61(0.68)$ & $1.37(0.03)$ & $1.39(0.03)$ & $1.28(0.08)$ \\
\hline Lisboeta (sw) (Lis) & $3.44(0.04)$ & $35.09(1.37)$ & $1.39(0.03)$ & $1.59(0.06)$ & $1.28(0.07)$ \\
\hline Tardif de Vignole (sw) (TaV) & $3.38(0.06)$ & $39.37(0.65)$ & $1.25(0.03)$ & $1.64(0.06)$ & $1.39(0.04)$ \\
\hline Saco 1 (sw) (Sa1) & $3.33(0.44)$ & $38.95(1.18)$ & $1.45(0.08)$ & $1.71(0.10)$ & $1.38(0.05)$ \\
\hline Saco 2 (sw) (Sa2) & $3.27(0.42)$ & $37.45(1.29)$ & $1.37(0.04)$ & $1.61(0.13)$ & $1.39(0.15)$ \\
\hline Morangão (sw) (Mor) & $3.49(0.20)$ & $37.59(0.11)$ & $1.33(0.01)$ & $1.61(0.08)$ & $1.41(0.10)$ \\
\hline Maringa (sw) (Mar) & $3.17(0.32)$ & $37.31(0.66)$ & $1.41(0.08)$ & $1.48(0.14)$ & $1.32(0.08)$ \\
\hline Sobral D’óbidos (so) (SoO) & $3.00(0.21)$ & $35.47(2.08)$ & $0.96(0.00)$ & $1.33(0.11)$ & $1.41(0.08)$ \\
\hline Martinho D’Óbidos (so) (MaO) & $2.96(0.22)$ & $36.53(2.27)$ & $1.01(0.05)$ & $1.33(0.09)$ & $1.32(0.03)$ \\
\hline Pedro Miguel D’óbidos (so) (PMO) & $3.00(0.24)$ & $36.53(1.85)$ & $1.03(0.05)$ & $1.36(0.07)$ & $1.37(0.06)$ \\
\hline Seixas (so) (Sei) & $2.92(0.23)$ & $32.96(1.65)$ & $1.13(0.03)$ & $1.27(0.08)$ & $1.28(0.10)$ \\
\hline Galega (so) (Gal) & $2.50(0.20)$ & $30.43(0.67)$ & $0.87(0.02)$ & $1.13(0.09)$ & $1.04(0.09)$ \\
\hline Garrafal rosa (so) (GaR) & $2.65(0.27)$ & $31.21(1.82)$ & $0.89(0.02)$ & $1.23(0.11)$ & $1.12(0.09)$ \\
\hline Garrafal negra (so) (GaN) & $2.57(0.27)$ & $30.41(0.52)$ & $1.15(0.02)$ & $1.26(0.04)$ & $1.25(0.06)$ \\
\hline Garrafal (so) (Gaf) & $2.51(0.25)$ & $30.73(0.35)$ & $1.13(0.03)$ & $1.18(0.07)$ & $1.14(0.11)$ \\
\hline
\end{tabular}

length was highly correlated with the size of the flower in all cases, while the petal width varied from 1.0 to $1.5 \mathrm{~cm}$, with the lowest values for the 'Galega' and the three 'Garrafal' sour cherries.

Leaves

The measured leaf parameters are shown in Table 2 as well as the two ratios: length/width of the leaf blade and length of the petiole/length of the leaf blade. The highest values for the basal angle occurred in 'Lisboeta' and 'Maringa' sweet cherries and the smallest values in the three 'D'Óbidos' sour cherries. The apical angle ranged between $60.0^{\circ}$ and $72.0^{\circ}$. The shortest petioles were the ones of the 'D'Óbidos' sour cherries, around $1.5 \mathrm{~cm}$ and the longest, around $4.6 \mathrm{~cm}$, in 'Lisboeta' and 'Francesa de Alenquer'. The size of the blade was larger in all sweet cherries, with length from 12 to $16 \mathrm{~cm}$ and width from 6 to 7 , while the same parameters in sour cherries varied from 7 to $12 \mathrm{~cm}$ and from 4 to $6 \mathrm{~cm}$ respectively. The calculated ratios, length/width of the blade and the petiole/leaf blade length were rather similar in all cases, with no marked differences between sweet and sour cherries; only in the case of the three varieties from Óbidos the petiole/leaf blade length ratios were lower, around 0.15 , while the rest of the varieties had values around 0.25 .

Fruits

The measured fruit parameters are shown in Table 3. The length of the stalk is short to medium, from 40 to $49 \mathrm{~mm}$, in most of the cases, being 'Lisboeta' sweet cherry the one with the longest stalk. The fruit cracking was low, less than $10 \%$ in most of the sour cherry varieties, except 'Garrafal' and 'Garrafal negra', with values around $20 \%$; sweet cherries had values between 24 and $50 \%$ except in the case of 'Tardif de Vignole' with a cracking percentage of 11; 'Burlat' was the variety with the highest cracking value, close to $50 \%$.

The volume of the endocarp varied in the sweet cherries from $0.44 \mathrm{~cm}^{3}$ in both 'Saco 1' and 'Saco 2' to 0.58 in 'Tardif de Vignole'; in the sour cherries it varied from $0.29 \mathrm{~cm}^{3}$ in 'Galega', to $0.46 \mathrm{~cm}^{3}$ in the three 'D'Óbidos' and in 'Garrafal negra'.

With reference to the total acidity, marked differences occurred among sweet cherries, with values from 5 to $9 \mathrm{~g} / \mathrm{l}$; within the sour cherries, the acidity was particularly high in most of the varieties, from 15 


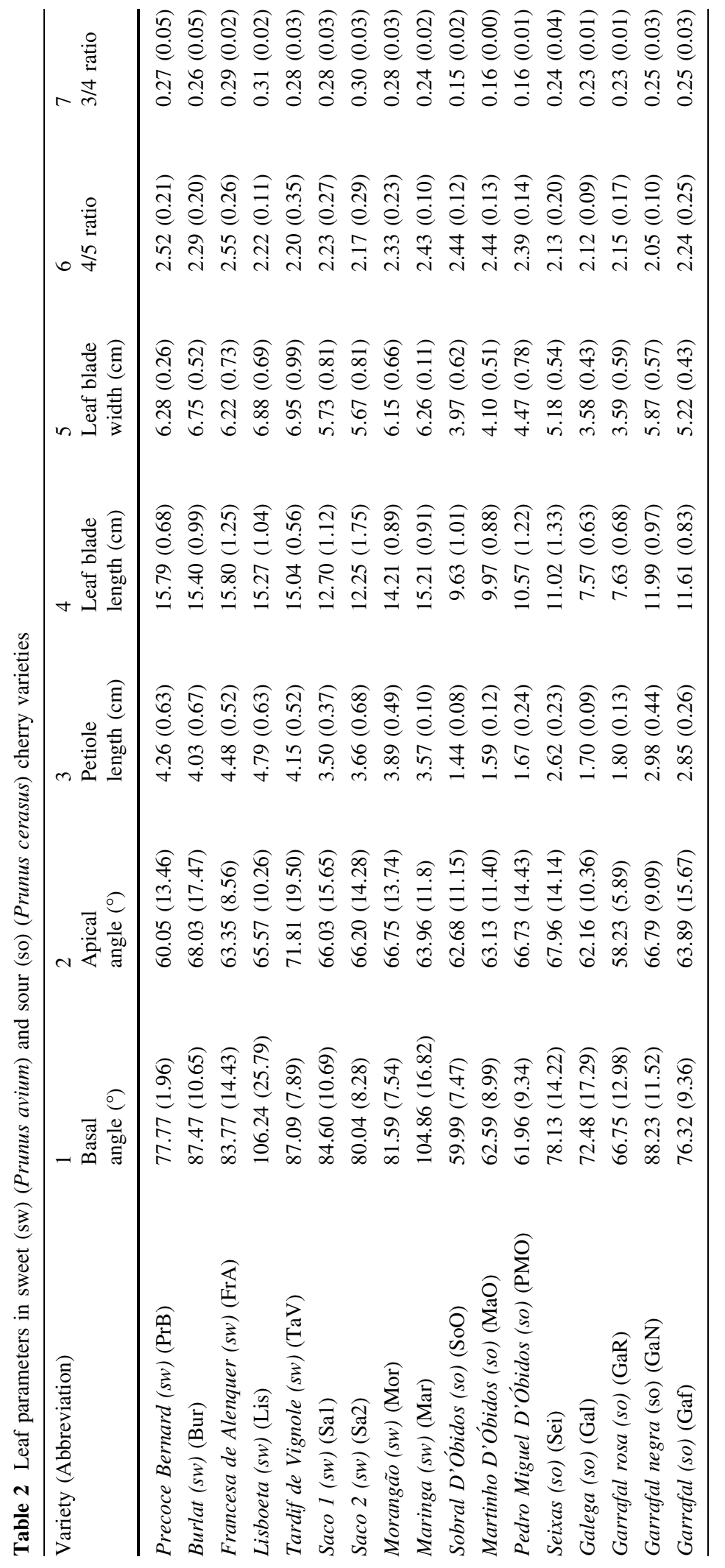




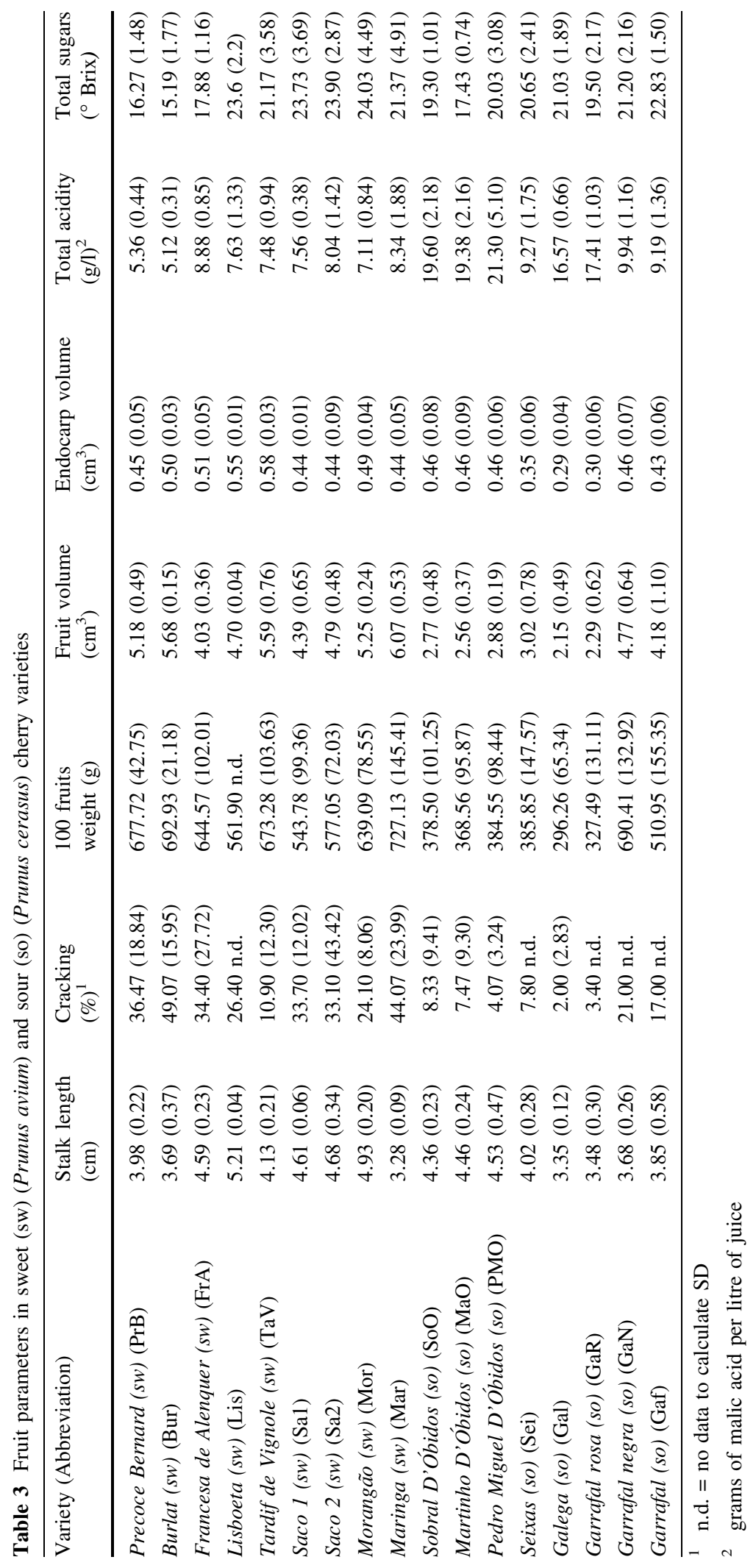


Table 4 Fruit characteristics of sweet (sw) (Prunus avium) and sour (so) (Prunus cerasus) cherry varieties

\begin{tabular}{|c|c|c|c|c|c|c|c|}
\hline Variety (Abbreviation) & $\begin{array}{l}\text { Fruit skin } \\
\text { colour }^{1}\end{array}$ & $\begin{array}{l}\text { Fruit flesh } \\
\text { colour }^{2}\end{array}$ & $\begin{array}{l}\text { Fruit } \\
\text { shape }^{3}\end{array}$ & Discol. $^{4}$ & $\begin{array}{l}\text { Leaves on } \\
\text { fruit stalk }\end{array}$ & $\begin{array}{l}\text { Firmness } \\
\text { of flesh }\end{array}$ & $\begin{array}{l}\text { Eating } \\
\text { quality }^{5}\end{array}$ \\
\hline Precoce Bernard (sw) (PrB) & M & $\mathrm{D}$ & $\mathrm{K}$ & Few and large & None & Intermediate & 8 \\
\hline Burlat (sw) (Bur) & M & $\mathrm{D}$ & $\mathrm{F}$ & Few and large & None & Intermediate & 8 \\
\hline Francesa de Alenquer (sw) (FrA) & M & $\mathrm{D}$ & $\mathrm{C}$ & None & None & Intermediate & 7 \\
\hline Lisboeta (sw) (Lis) & $\mathrm{B}$ & $\mathrm{D}$ & $\mathrm{E}$ & None & None & Intermediate & 7 \\
\hline Tardif de Vignole (sw) (TaV) & M & $\mathrm{D}$ & $\mathrm{F}$ & None & None & Intermediate & 7 \\
\hline Saco 1 (sw) (Sa1) & $\mathrm{V}$ & $\mathrm{C}$ & $\mathrm{F}$ & Few and large & None & Firm & 7 \\
\hline Saco 2 (sw) (Sa2) & M & $\mathrm{D}$ & $\mathrm{R}$ & Few and large & None & Firm & 8 \\
\hline Morangão (sw) (Mor) & $\mathrm{W}$ & $\mathrm{C}$ & $\mathrm{K}$ & Few and large & None & Firm & 8 \\
\hline Maringa (sw) (Mar) & M & $\mathrm{D}$ & $\mathrm{K}$ & None & None & Intermediate & 7 \\
\hline Sobral D’óbidos (so) (SoO) & $\mathrm{V}$ & $\mathrm{R}$ & $\mathrm{F}$ & None & Few & Soft & 2 \\
\hline Martinho D’Óbidos (so) (MaO) & $\mathrm{V}$ & $\mathrm{R}$ & $\mathrm{F}$ & None & Few & Soft & 2 \\
\hline Pedro Miguel D’óbidos (so) (PMO) & $\mathrm{V}$ & $\mathrm{R}$ & $\mathrm{F}$ & None & Few & Soft & 2 \\
\hline Seixas (so) (Sei) & M & $\mathrm{D}$ & $\mathrm{F}$ & None & None & Soft & 3 \\
\hline Galega (so) (Gal) & $\mathrm{V}$ & $\mathrm{R}$ & $\mathrm{F}$ & None & None & Soft & 1 \\
\hline Garrafal rosa (so) (GaR) & $\mathrm{V}$ & $\mathrm{R}$ & $\mathrm{F}$ & None & None & Soft & 3 \\
\hline Garrafal negra (so) (GaN) & W & $\mathrm{D}$ & $\mathrm{C}$ & Small black dots & None & Soft & 4 \\
\hline Garrafal (so) (Gaf) & $\mathrm{Y}$ & $\mathrm{P}$ & $\mathrm{F}$ & Few and large & None & Soft & 7 \\
\hline \multicolumn{8}{|c|}{${ }^{1} \mathrm{~B}=$ black; $\mathrm{M}=$ mahogany; $\mathrm{W}=$ wine red; $\mathrm{V}=$ vermilion; $\mathrm{Y}=$ vermilion on yellow ground colour } \\
\hline \multicolumn{8}{|c|}{${ }^{2} \mathrm{D}=$ dark red; $\mathrm{R}=$ red; $\mathrm{P}=$ pink; $\mathrm{C}=$ cream white, cream yellow } \\
\hline \multicolumn{8}{|c|}{${ }^{3} \mathrm{~K}=$ kidney-shaped $; \mathrm{F}=$ flat-round $; \mathrm{R}=$ round $; \mathrm{E}=$ elongate $; \mathrm{C}=$ cordate } \\
\hline \multicolumn{8}{|l|}{${ }^{4}$ Discolorations on the fruit surface } \\
\hline 5 Eating quality: 1 = extremely poor; & $=$ poor; & fair; $7=$ & 0 & en & & & \\
\hline
\end{tabular}

to $20 \mathrm{~g} / \mathrm{l}$, except for 'Seixas', 'Garrafal negra' and 'Garrafal' which have acidity close to $10 \mathrm{~g} / \mathrm{l}$. The sugar levels showed a less marked variation, with values from 15 to $25^{\circ}$ Brix in all cases.

With respect to the qualitative fruit characteristics, a marked variability can be observed among varieties (Table 4). Two sweet cherry varieties, 'Saco1' and 'Morangão', have vermilion or wine red skin colour and cream white flesh colour, while the others are darker, both externally and internally. The predominant shape is flat-round with other shapes in sweet and in sour cherries. The eating quality was good in all sweet cherries as well as in 'Garrafal' sour cherry.

Leaves on stalk were only present in the 'D'Óbidos' varieties. The flesh was soft in all cases.

The weight and the volume of the fruit were highly correlated, being the fruits of the sour cherries smaller in all cases, except in 'Garrafal negra', with a size similar to the sweet cherries.

\section{Trees}

The evaluation of the trees is summarized in Table 5. Vigour was quantified with reference to 'Burlat' in sweet cherries. The values ranged from 50 to 100 in the different varieties. The dominant habit of the trees was upright, although cases of spreading and drooping were also present. With reference to the compatibility of the scion, it was intermediate or good in most of the cases.

Multivariate analysis

Multivariate analysis of the morphometrical as well as the morphological parameters as set out in "Material and methods" resulted in the dendrogram of Fig. 1. Two branches are clearly visible that separate the sweet from the sour cherries at a distance of 1.60 . Within the sweet cherries, 'Saco1' and 'Morangão' are relatively close as well as 'Burlat' and 'Precoce 
Table 5 Tree parameters in sweet (sw) (Prunus avium) and sour (so) (Prunus cerasus) cherry varieties

1 Reference (100): 'Burlat' for sweet cherry trees; 'Garrafal' for sour cherry trees

Fig. 1 Dendrogram obtained with the UPGMA method by using morphometric plus morphological characters in the studied sour and sweet cherry cultivars. See Table 1 for abbreviations

\begin{tabular}{|c|c|c|c|}
\hline Variety $^{1}$ (Abbreviation) & Tree vigour $^{1}$ & Tree habit & $\begin{array}{l}\text { Scion/rootstock } \\
\text { compatibility }\end{array}$ \\
\hline Precoce Bernard (sw) (PrB) & 93 & Spreading & Good \\
\hline Burlat (sw) (Bur) & 100 & Upright & Good \\
\hline Francesa de Alenquer ( $s w)$ (FrA) & 52 & Upright & Intermediate \\
\hline Lisboeta (sw) (Lis) & 46 & Upright & Intermediate \\
\hline Tardif de Vignole $(s w)(\mathrm{TaV})$ & 68 & Upright & Good \\
\hline Saco 1 (sw) (Sa1) & 60 & Upright & Intermediate \\
\hline Saco 2 (sw) (Sa2) & 52 & Drooping & Good \\
\hline Morangão (sw) (Mor) & 53 & Upright & Good \\
\hline Maringa (sw) (Mar) & 80 & Spreading & Good \\
\hline Sobral D’Óbidos (so) (SoO) & 83 & Drooping & Good \\
\hline Martinho D’óbidos (so) (MaO) & 87 & Drooping & Good \\
\hline Pedro Miguel D'Óbidos (so) (PMO) & 98 & Drooping & Good \\
\hline Seixas (so) (Sei) & 90 & Upright & Intermediate \\
\hline Galega (so) (Gal) & 78 & Spreading & Poor \\
\hline Garrafal rosa (so) (GaR) & 68 & Spreading & Poor \\
\hline Garrafal negra (so) (GaN) & 85 & Upright & Poor \\
\hline Garrafal (so) (Gaf) & 100 & Upright & Poor \\
\hline
\end{tabular}

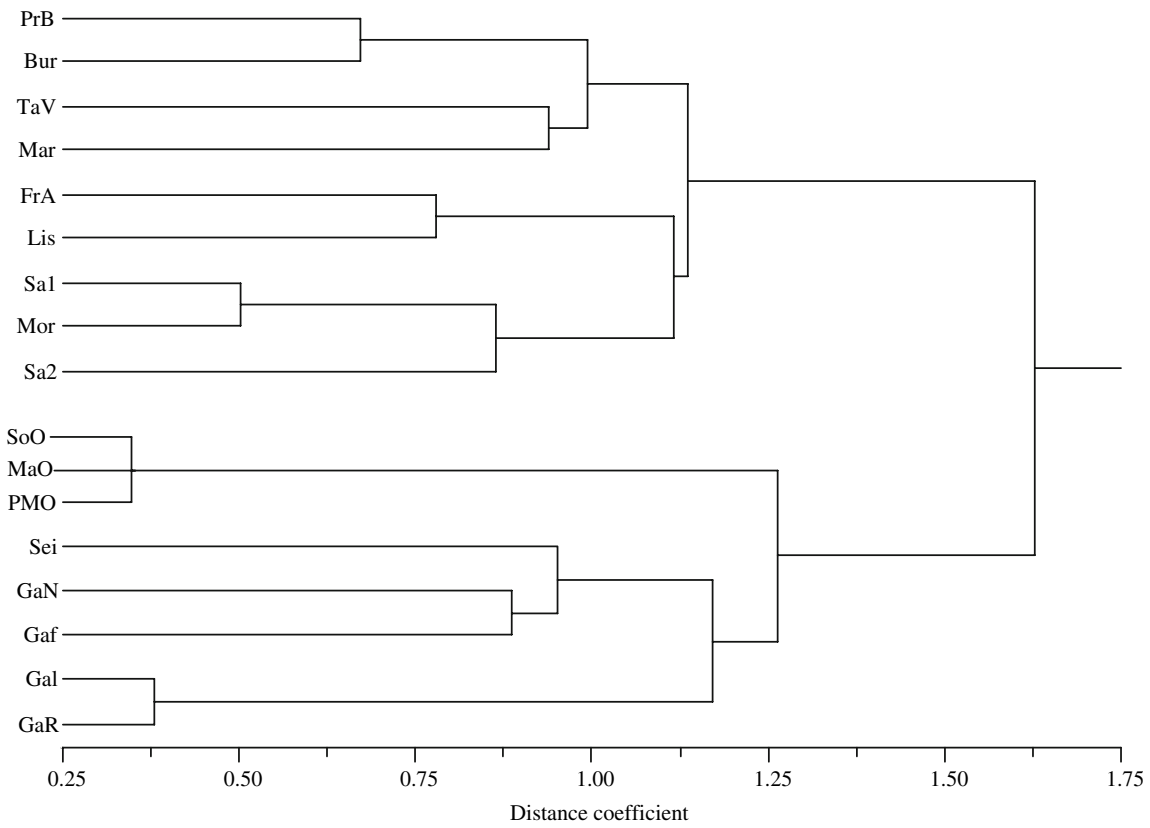

Bernard'. 'Francesa de Alenquer' and 'Lisboeta' emerge at a distance of about 0.76 . With respect to the sour cherries, the three from D'Óbidos' are very closely related and they probably belong to the same variety. Also 'Galega' and 'Garrafal rosa' are very similar and again they are probably the same variety.

\section{Discussion}

Description of the morphological characteristics is the usual methodology accepted from a legal point of view for patenting and registration of varieties (Badenes 1991). 
Several quantitative and qualitative evaluations showed a clear difference between sweet and sour cherries, with a more marked variability within the sweet cherries group, probably due to the more intense domestication processes that have taken place. With reference to the flower diameter, 'Burlat' and 'Precoce Bernard' are the two varieties with the largest open flower diameters, that may improve pollination by insects.

Fruit characterization includes several parameters of interest from the commercial viewpoint. The length of the peduncle has been considered to be a good measure for identification of some varieties (Christensen 1970). 'Burlat' and 'Maringa' are the two sweet cherries with the shortest peduncles, that are apparently dominant to the long ones (Brown et al. 1996). Cracking incidence is another characteristic related to the breeding process. A more sensible scale for testing is $1-5$ for readings ranging from $82 \%$ (high) to 24\% (low) (Christensen 1970). Tendency to fruit cracking is below $46 \%$, except for 'Burlat', which has a value of $49 \%$. Fruit size is medium or large in all sweet cherries as well as in 'Garrafal negra' and 'Garrafal'; this could be explained because the last variety might be a hybrid between sweet and sour cherry, explaining the intermediate characteristics shown. This agrees with Hillig and Iezzoni (1988) who proposed a hybrid between the two species. The two sour cherry cultivars 'Galega' and 'Garrafal rosa" are very small in size. The endocarp represents in most of the cases less than $10 \%$ of the fruit volume being relatively larger in the three 'D'Óbidos' varieties; these values correspond to those obtained in an evaluation of sour cherry cultivars in Denmark (Christensen 1970, 1977). Fruit size, peduncle length and maturation time are the three main descriptors for characterization (Christensen 1970; Hjalmarsson and Ortiz 2000) because of their relevance to commercial growing. As expected, the total acidity is more marked in all sour cherries, with values from 9 to $20 \mathrm{~g} / \mathrm{l}$, being 'Seixas', 'Garrafal negra' and 'Garrafal' the ones with lower acidity. The ratio between sugars and acidity oscillates from 2.0 to 3.4 in sweet cherries, but it is close to 1.0 in sour cherries except in the three mentioned cultivars. These two parameters are closely related to the eating quality of the fruit.

With respect to the cracking susceptibility, it seems that it is directly correlated to the sugar level in the fruit, probably due to osmotic regulations of the cells of the mesocarp.

External and internal colour of the fruit is an important characteristic from a commercial viewpoint. 'Lisboeta' is the only variety with external black colour, while 'Saco1' and 'Morangão' are the two varieties with cream white pulp. Pictures of the varieties studied can be seen in a recent publication (Cordeiro Rodrigues 2004).

The conclusion of this study is that the conservation of the autochthonous sweet and sour cherry cultivars is highly recommended. The results suggest that the three 'D'Óbidos' cultivars belong to the same variety, as well as the cultivars 'Galega' and 'Garrafal rosa'. On the other hand, the two 'Saco' cultivars, 'Saco1' and 'Saco2' are different varieties. Molecular studies carried out on these varieties in our laboratory (Cordeiro Rodrigues 2003) have confirmed these results.

The research group is currently looking for new germoplasm sources in other Portuguese regions, with the intention of establishing new plantations and preservation autochthonous plant material of sweet and sour cherries.

\section{References}

Badenes ML (1991) Caracterización e identificación de variedades de albaricoquero por métodos pomológicos y bioquímicos. Tesis doctoral, Universidad Politécnica de Valencia, Valencia (Spain)

Beaver JA, Iezzoni AF (1993) Allozyme inheritance in tetraploid sour cherry (Prunus cerasus L.). J Amer Soc Hort Sci 118:873-877

Brown SK, Iezzoni AF, Fogle HW (1996) Cherries. In: Janick J, Moore JN (eds) Fruit breeding, Tree and tropical fruits, vol I. John Wiley \& Sons, Inc, pp. 213-255

Cordeiro-Rodrigues L (2003) Caracterización morfológica, isoenzimática y molecular de variedades de cerezo (Prunus avium L.) y de guindo (Prunus cerasus L.) portuguesas. Tesis Doctoral. Universidad Politécnica de Madrid. Madrid, Spain

Cordeiro-Rodrigues L (2004) Caracterização morfológica e morfométrica de variedades portuguesas de cerejeira e ginjeira. Edited by COTHN Centro Operativo e Tecnológico Hortofrutícola Nacional. ISBN: 972-8785-02-X

Christensen JV (1970) Numerical studies of morphological distinction marks in sweet cherry cultivars. Identification key for 34 cultivars. Tidsskr Planteavl 74:44-74

Christensen JV (1977) Evaluation and numerical studies of qualitative and morphological characteristics of 49 sweet cherry cultivars. III. Saertryk af Tidsskrift for Planteavl 81:148-158 
Hedrick UP (1915) Cherries of New York. J.B. Lyon Co., Albany, New York

Hillig KW, Iezzoni AF (1988) Multivariate analysis of a sour cherry germplasm collection. J Amer Soc Hort Sci 113:928-934

Hjalmarsson I, Ortiz R (2000) In situ and ex situ assessment of morphological and fruit variation in Scandinavian sweet cherry. Sci Hortic 85:37-49

IBPGR (1985) Cherry descriptor list.In: H Schmidt, J VittrupChristensen, R Watkins, RA Smith (eds) CEC Secretariat, Brussels (1985) AGPG: IBPGR/85/37, November (1985)

Ingram C (1948) Ornamental cherries. London

Instituto do Ambiente (2003) Solos. Ministério do Ambiente e do Ordenamento do Território. In: http://www.iambiente.pt/atlas/est/index.jsp
Linnaeus C (1753) Species Plantarum, 1st edn. Holmiae Marshall RE (1954) Cherries and Cherry Products. In: Economic crops. Interscience, ed., vol. 5. New York

Olden EJ, Nybom N (1968) On the origin of Prunus cerasus L. Hereditas 70:3321-3323

Rohlf FJ (1990) NTSYS-pc. Numerical taxonomy and multivariate analysis system. Version 1.60. Exeter Software, New York

Watkins R (1995) Cherry, plum, peach, apricot and almond Prunus spp. (Rosaceae). In: Smartt J, Simmonds NW (eds) Evolution of crop plants. Longman Scientific \& Technical, New York, pp. 423-428 